\title{
Bulgaristan'ın Asimilasyon Politikalarına Karşı Alvanlar (Yablanovo) Direnişi (17-18-19 Ocak 1985)
}

\author{
Hasan DEMIRHAN*
}

Öz

1984-1989 yılları arasında Bulgaristan Komünist Parti yönetimi ülkede yaşayan Türklerin asıllarının Bulgar olduğunu iddia eden Yeniden Doğuş (Soya Dönüş) Süreci olarak tanımladıkları bir kampanyayı başlattı. Bu kampanya ile birlikte Bulgaristan'da yaşayan soydaşlarımızın Türkçe konuşması, Türk müziği dinlemesi, kurban kesmesi, çocuklarını sünnet ettirmesi, cenazelerinde veya düğünlerinde dinsel ve geleneksel uygulamaları, Türklüğün simgesi gibi görülen bazı kıyafetleri giymeleri yasaklandı. Bu yasakların yanı sıra, 1984 yılının Aralık ayı itibariyle Bulgaristan’da yaşayan soydaşlarımızın isimleri Bulgar isimleri ile değiştirilmeye başlandı. İsim değiştirme uygulaması, 17-18-19 Ocak günlerinde İslimye (Sliven) iline bağlı Kazan (Kotel) ilçesinin bir köyü olan Alvanlarda (Yablanovo) uygulamaya konuldu. Ancak Alvanlar (Yablanovo) köyü halkı isimlerini değiştirmeye gelen Bulgar Komünist Partisi yöneticilerine toplu bir şekilde direniş gösterdi. Gerlovo bölgesindeki diğer köyler de Alvanları (Yablanovo) bu direnişte yalnız bırakmadılar. Bulgar komünist idarecileri 17 ve 18 Ocak'ta giremedikleri köye 19 Ocak sabahı Bulgaristan'in en büyük zırhlı birliği olan İslimye (Sliven) Zırhlı Birliği’nin yardımı ile girebildiler. Bulgar ordusunun tanklarına karşı ellerindeki taş ve sopalarla üç gün direnerek büyük bir kahramanlık örneği gösteren Alvanlılar Bulgaristan Türklerinin tarihinde çok önemli bir iz bıraktılar.

Anahtar Kelimeler: Bulgaristan, Azınlık, Asimilasyon, Alvanlar (Yablanovo), Direniş

\footnotetext{
* Dr. Öğr. Üyesi, Kırklareli Üniversitesi, Fen-Edebiyat Fakültesi, Tarih Bölümü, Kırklareli, Türkiye. Elmek: hasandemirhan_@hotmail.com https://orcid.org/0000-0002-5868-8317
} 


\title{
Alvanlar Resistance Against the Assimilation Policies of Bulgaria \\ (17-18-19 January 1985)
}

\begin{abstract}
Between 1984 and 1989, the Communist Party of Bulgaria launched a campaign called the Rebirth (Back To Basics) Process, which claimed that the Turks living in the country were originally Bulgarian. With this campaign, Turks in Bulgaria were prohibited from speaking Turkish, listening to Turkish music, slaughtering sacrifices, circumcising their children, religious and traditional practices at their funerals or weddings, and wearing wearing certain clothes that were seen as symbols of Turkishness. In addition to these prohibitions, as of December 1984, the names of our citizens living in Bulgaria began to be replaced with Bulgarian names. The name change was implemented in Alvanlar (Yablonova), a village of Kazan (Kotel) district of Islimye (Sliven) province on 17-18-19 January. However, the people of the village of Alvanlar (Yablanovo) massively resisted the leaders of the Bulgarian Communist Party who came to change their names. Other villages in the Gerlovo region did not leave the Alvanlar alone in this resistance. On January 17 and 18, the Bulgarian communist rulers could not enter the village, and on the morning of January 19, they were able to enter the village with the help of the Sliven Armored Unit, the largest armored unit in Bulgaria. Resisting the tanks of the Bulgarian army with stones and sticks in their hands for three days, the Alvanlar people showed a great example of heroism and left a very important mark in the history of the Bulgarian Turks.
\end{abstract}

Keywords: Bulgaria, Minority, Assimilation, Alvanlar (Yablanovo), Resistance 


\section{Extended Summary}

After five centuries of Ottoman sovereignty, the Bulgarian State gained its autonomy with the Treaty of Berlin in 1878 and its independence with the Istanbul Protocol signed in 1909. When Bulgaria was founded, many minority groups such as Turks, Macedonians, Vlachs and Gypsies lived within the borders of the country. Bulgarian nationalists saw this as a threat to Bulgaria's integrity and attempted to assimilate the minorities to create a homogeneous Bulgarian nation. During the years of the Ottoman-Russian War (1877-1878) and the Balkan Wars (1912-1913) the Turks, which makes up half of Bulgaria's population and the largest minority in the country, were massacred, forced to migrate or tried to be Christianized and ultimately the Bulgarians had the majority in the country.

Until the Alvanlar (Yablanovo) Resistance (1985), which is the subject of our article, Bulgaria was ruled by different political regimes and many different governments. However, the policy of assimilating minorities has been implemented for years as a common goal followed by all regimes. As a result of these policies, the population rate of Turks in Bulgaria decreased to around $10 \%$ in the 1920s and has never exceeded this rate since then. When the Turkish population in Bulgaria increased, the Bulgarian governments forced our compatriots to migrate to the homeland. With the mass migration in 1951, 154.393 Turks and between the years 1969 and 1978, 130.000 Turks emigrated to Turkey in accordance with the treaty signed between the two countries to consolidate fragmented families.

Bulgaria gave the Muslim Pomaks (1948-1952, 1962-1964 and 19711974), the Muslim Gypsies (1953-1954, 1965 and 1981-1983), the Tatars and Albanians ( in the summer of 1984) their Bulgarian names and completed the assimilation of these minority groups on paper. For the assimilation of the Turks, in 1984, the Bulgarian Communist Party central administration launched a campaign called the Rebirth (Back To Basics) Process. In this campaign, 
they claimed that Turks living in Bulgaria were originally Bulgarian and the ancestors of the Turks in Bulgaria were converted to Islam and Turkified by centuries of Ottoman rule by sword. In order to prove these claims, Bulgarian authorities published many unrealistic scientific books, theses and brochures. In daily newspapers in Bulgaria, they published unrealistic news proving that the Turks' ancestors were Bulgarian. In addition to these claims to assimilate the Turks, they have banned their beliefs, languages, traditions and customs. Between 1984 and 1989, it was forbidden to speak Turkish, to listen to Turkish music, to wear Turkish clothes such as shalwar, to celebrate religious holidays, to go to the mosque, to circumcise children, and to practice any Turkish tradition at weddings or funerals. After December 1984, the Bulgarian communist administrators came to the final stage of the assimilation process and raided the Turkish villages with the security forces. They forcibly changed the names of the Turks. The Turks who resisted changing their names were sent to prisons or concentration camps.

On January 17-18-19, it was time to change the names in Alvanlar (Yablanovo) village of the Kazan (Kotel) district of the Islimye (Sliven) province in Bulgaria. However, the Alvanlar people refused to change their names and decided to resist collectively. In many parts of Bulgaria, the Turks had resisted the name change campaign, but these resistances were made individually. In Bulgaria, only in the village of Alvanlar (Yablanovo) (with the support of other Gerlovo villages) there was a mass resistance to the Bulgarian Communist Administration's renaming campaign. This was what made the Alvanlar (Yablanovo) Resistance special.

When I first heard the story of the resistance of the village of Alvanlar (Yablanovo), I wondered why this village was different from the others and what the Alvanlar people did during these three days. I applied to written sources about this story of resistance. However, it was almost impossible to find written sources in the literature. There were only a few inconsistent memories in the narrative of the events.So, in order to write the story of the resistance in the village of Alvanlar (Yablanovo), I decided to listen to the stories of those who witnessed the event and conduct an oral history study. My aim in this study was 
to write stories of people who struggled in this great resistance, who risked to be tortured in prisons and concentration camps in Bulgaria for years to defend their Turkish and Muslim identities, and to reveal their sense of belonging that motivated them with their own narratives. I did interviews with people who came to Turkey in 1989, settled in different provinces and personally lead the resistance. In 2016, I visited Alvanlar (Yablanovo) and personally saw and photographed the places mentioned in the narratives. I listened to those who were still in the Alvanlar (Yablanovo) and witnessed the 1985 events.

On 17-18-19 January 1985, the people of Alvanlar showed great courage in Bulgaria, an iron curtain country and resisted the Bulgarian Communist Party administrators and security forces for three days. The most important factor motivating them in this resistance was their desire to protect their identities, beliefs, families and assets that they had and that they could not give up. 



\section{Giriş}

Alvanlar (Yablanovo) Köyü Gerlovo bölgesinin en büyük köyü ve bağl1 olduğu Kazan (Kotel) ilçesi'ne 27 km. uzaklıkta olan bir yerleşim yeridir. Köyün etrafı yüksek dağlarla ve yeşilin her tonunu barındıran ormanlarla çevrilidir. Alvanların (Yablanovo) idari olarak bağlı olduğu Kazan (Kotel) ilçesinden köye doğru yaklaştığınızda, sizleri köyün deresinin üzerine kurulmuş olan büyük taş köprü karşılar. Kafanızı kaldırıp sağ tarafa baktığınızda bir dağın köye bakan yamacında Alvanların (Yablanovo) kuruluşunda önemli bir rol oynayan Ali Koç Baba’nın türbesini görürsünüz. Köye iki yanı yüksek ağaçlarla sıralı bir asfalt yoldan giriş yapıyorsunuz. Bu yol, aynı zamanda 19 Ocak 1985 tarihinde Alvanlı (Yablanovo) soydaşlarımızın isimlerini değiştirmek için köye giren İslimye (Sliven) zırhlı birliklerinin de giriş noktasıdır. Alvanlılar, 1984 yılında Bulgaristan'da başlatılan ve Türklerin asıllarının Bulgar olduğunu iddia eden Yeniden Doğuş Süreci’ne karş1 17-18-19 Ocak 1985 'te örgütlü ve toplu bir direniş gösterdiler. 1985 yılının ilk günlerinde dondurucu soğuğa rağmen köylerinde yaktıkları büyük ateşlerin etrafında bir bütün olarak direnen Alvanlılar, Bulgaristan'ın diğer bölgelerinde gösterilen bireysel tepkilerden ve direnişlerden çok daha etkili oldular ve bizlere araştırılması gereken güzel bir direniş hikayesi bıraktılar.

Alvanlar (Yablanovo) direnişini yazmaya karar verdiğimde benim için en büyük sıkıntı bu konu ile ile ilgili yazılı ve görsel materyalin azlığı oldu. Zira Bulgaristan, Alvanlar (Yablanovo) direnişinin gösterildiği günlerde komünist rejim ile yönetilen bir demir perde ülkesiydi. Bulgaristan' da ya da diğer demir perde ülkelerinde, devletin veya komünist partinin yaptığı eylemlere karşı bir direnişin olması ya da bu direniş hakkında haber yapılması imkansızdı. Bu yönüyle Alvanlar (Yablanovo) Direnişi hakkında ulusal veya uluslararası birkaç gazete yazısı ve olaylardan çok sonra yazılan hatıratlar dışında yazılı bir kaynağa ulaşamadık. Yazılı kaynaklara ekleyebileceğimiz diğer materyaller ise olayların yaşanmasından aylar sonra bu bölgeye yapılan sınırlı sayıdaki gezilerin notlarıydı. Bu şartlar altında Alvanlar (Yablanovo) Direnişi’ni yazabilmek için tanıklar ile görüşme 
yapmak bir zorunluluk haline geldi. Ayrıca, yeterli bir kayda ulaşma imkânımız olsa bile çalışmamızın detaylandırılması için yine de sözlü tarih yöntemini kullanmamız gerekirdi. Bizde 17-18 ve 19 Ocak 1985 günlerinde Yeniden Doğuş Süreci adı verilen kampanyada Türk isimlerinden vazgeçmek istemeyen ve bu uygulamaya karşı kahramanca direnen Alvanlar köyünün direniş hikayesini, direnişte rol oynayan ve bu direnişlerinden dolayı yıllarca Bulgar hapishanelerinde ve cezaevlerinde yatan kahramanlar ve onların en yakınları ile yapmış olduğumuz sözlü tarih çalışmalarına dayandırdık. Ayrıca çalışmamızda giriş bölümünün ardından, Bulgaristan' da yüzyıllardır yaşamakta olan soydaşlarımıza karşı uygulanan asimilasyon politikalarına kısaca değinerek, 1985 yılında Alvanlar'da (Yablanovo) yaşananların temelleri hakkında kısaca bilgi verilmiştir.

\section{Bulgaristan'da Türklere Uygulanan Asimilasyon Politika- larının Kısa Bir Tarihi}

Bulgaristan, beş asırlık Osmanlı hâkimiyetinden sonra 1877-1878 Osmanlı Rus Harbi neticesinde imzalanan Ayastefanos Antlaşması ile özerkliğini, 1909 yılında imzalanan İstanbul Protokolü ile bağımsızlığını kazandı. (Demirhan, 2017, s. 361-362). Bulgaristan'1n kurulduğu topraklarda 1877-1878 Osmanlı Rus Harbi'nden önce yapılan nüfus sayımlarında nüfusun \%52,7'sini Türkler oluşturuyordu. Böyle bir nüfus oranına sahip olan topraklarda üniter bir Bulgar Devleti kurmak ilk bakışta imkansız görünmekteydi. 1877-1878 Osmanlı Rus Savaşı öncesinde Rusların yaptığı değerlendirmelerde, kurulacak olan Bulgar Devleti'nin temellerinin sağlam olmayacağı ve kurulan bu Bulgar Devleti'nin parçalanıp iki milletli bir federasyona dönüşebileceği yazılmaktaydı. Bunu önlemek için Panislavistler, yerli Türk Müslüman halkını ya o topraklardan kovmak, ya da k1liçtan geçirmek gerektiği düşüncesini ortaya att1lar. Ruslar bu kararla 1877-1878 Osmanlı Rus Harbi'ni bir soykırım savaşına dönüştürerek, Tuna ve Edirne vilayetlerinde yaşayan yaklaşı 600.000 Türk'ü zorla göç ettirdiler ve yaklaşık 350.000 Türk'ü de vahşice öldürdüler. Bu süreçte Türklerin mülkleri yağmalandı. Okulları ve mescitler gibi tüm kurumları saldırıya uğradı. Türk Müslüman nüfusu Bulgaristan'da azınlık statüsüne dönüştürüldü (Memişoğlu, 1992, s. 116). Bulgaristan'daki Türk nüfusuna vurulan 
ikinci ağır darbe de Balkan Savaşları sırasında gerçekleşti. Bu savaşta Osmanlı Devleti ile karşı karşıya gelen Bulgaristan ülkesinde azınlık statüsünde bulunan Türklerin mallarına el koydu, camileri ve vakıfları yıktı, müslümanları zorla hristiyanlaştırmaya çalıştı(Demirhan, 2017, s. 363). Balkan Savaşları'nda yaklaşık olarak 200.000 soydaşımız Türkiye'ye göç etti(Yıldırım, 2018, s. 58). Bu zor yıllardan sonra 1919-1923 yılları arasında Bulgaristan'da iktidara gelen Çiftçi Partisi döneminde Türkler kısa süreliğine de olsa rahat bir nefes aldılar(Dayığlu, 2005, s. 171). Ancak 1923 yılında Çiftçi Partisi Hükümeti bir askeri darbe ile yıkıldı ve 1944 yılına kadar Bulgaristan'da faşist iktidarların dönemi başladı. Bu yıllarda Bulgaristan'da yaşayan soydaşlarımız için hayat çok zordu. Türklere ait okullar kapatıldı. Türkçe çıkan gazeteler yasaklandı. Bulgaristan Türklerinin Türkiye ile olan bağları koparıldı(Şimşir, 2012, s. 34). Bulgaristan'ın İkinci Dünya Savaşı'na Almanya'nın yanında dahil olması üzerine Rus orduları 8 Eylül 1944'de Bulgaristan'ı işgale başladı ve Sovyetler Birliği'nin desteği ile 9 Eylül 1944'de askeri bir darbe yapan Vatan Cephesi, iktidarı ele geçirdi. 1946 da Bulgaristan'da krallık rejimine son verildi ve 15 Eylül'de Cumhuriyet ilan edildi. 27 Eylül 1946'da yapılan seçimlerde Bulgaristan Komünist Partisi çoğunluğunu oluşturduğu Vatan Cephesi'ni tekrar iktidar yaptı. Böylece Bulgaristan'da 1989'a kadar sürecek olan komünizm dönemi başladı(Dayığlu, 2005, s. 275-276). İktidara gelen komünistler de kısa sürede Türk azınlığa verdikleri sözleri unuttular ve kendilerinden önceki faşist idareler gibi Türkleri asimile etme çabalarına giriştiler.

Bulgaristan Meclisi 27 Eylül 1946 tarihinde Türk okullarının devletleştirilmesi ile ilgili yasa tasarısını kabul etti(Memişoğlu, 1995, s.140). Bu yasa tasarıs1 12 Ekim 1946'da Bulgar resmi gazetesinde yayınlandı ve Türk Özel Okulları tarihe karıştı. Türk cemaati artık kendi okullarını açamayacak ve eski okullarının tümünü devlete terk edecekti. Ders programlarında ve öğretmen kadrolarında hemen bir değişiklik yapılmadı ancak karar yetkisi Türklerden Bulgarlara geçmişti. Böylece bütün uluslararası antlaşmalar bir yana koyularak Türk azınlık eğitimi Bulgarların insafına bırakılıyordu(Şimşir, 2012, s. 209). İktidara gelen komünistlerin Türk azınlığa vurdukları ikinci darbe de tarım sektöründe görüldü. 1945 yılında tarımda kollektifleşmeye gidilmesine karar veri- 
lerek Emek Kooperatifi Tarım İşletmelerinin (TKZS) kurulmasına karar verildi. Ancak bu uygulamaya sınırlı derecede bir katılım gerçekleşti. Bunun üzerine 20 Temmuz 1951 tarihinde Bakanlar Kurulu kararıly Tarım Bakanlığı, Bulgaristan Türklerinin yaşadığı bölgelerdeki Tarım Kooperatif İşletmeleri'nden birini her şeyi ile örnek bir kooperatif durumuna getirmekle görevlendirdi. Türk köylülerinin büyük çoğunluğu bu tarım kooperatiflerine girmeyi reddetti. Kooperatife girenler fakir köylülerdi. Orta halli çiftçiler kooperatiflere girmede tereddüt etti. Komünist partinin Beşinci Kongresi'nin (1948) kararlarından sonra, 1950'li y1llarda zor kullanılarak kooperatifleştirmede "kitleleştirme" hareketi başladı. 1959 yılında Bulgaristan'da toprağın \%96's1 kooperatifleştirildi. Bu durum \%90 çiftçi olan Türkleri çok etkiledi. Türklerin özel mülkleri kooperatifleştirilince köylerdeki Türkler kendi tarlalarından, bağlarından, bahçelerinden; şehirdekiler ise kendi özel dükkanlarından, atölyelerinden yoksun kaldılar(Memişoğlu, 2002, s.621-622)

Bulgaristan Türkleri yaşanan bu zor zamanlardan sonra 1947 ve 1948 yıllarında Türk yetkililere anavatana göç için başvurmaya başladılar. Bulgaristan Türkleri geleceklerinden endişeliydiler ve kendileri gelemezlerse en azından çocuklarını Türkiye'ye göndermek için çabalıyorlardı. Bulgar hükümeti çok az sayıda Türk vatandaşına Türkiye'ye göç için vize verdi. 1947 yılında 1763, 1948 yılında 1514 ve 1949 y1lında 1670 kişi serbest göçmen olarak Bulgaristan’dan Türkiye'ye gelebilmişti. Eylül 1949'da Bulgar Hükümeti tutum değiştirdi ve göç etmek isteyen Türklere daha kolay vize vermeye başladı. 1950 yılının Ağustos ayı başına kadar 26.788 kişiye Türkiye'ye göç için vize verdi. 10 Ağustos 1950 tarihinde ise Bulgar Hükümeti, Türkiye'ye bir nota vererek sert bir dille Bulgaristan Türklerinden 250 bin kişinin 3 ayda Türkiye'ye göçmen olarak alınmasını istedi. Bu Türkiye'nin tepkisine yol açtı. Bulgar yetkililer resmen Türklere bir tehcir uyguluyorlardı(Şimşir, 2012, s. 232-236). İki ülke arasındaki karşılıklı sert notaların ardından Türkiye'ye 1950-1951 yıllarında toplam olarak 154.393 soydaşımız göç etti. Bulgar hükümeti 30 Kasım 1951'de göçü yasakladı ve Bulgaristan Türklerinin ellerindeki pasaportları topladı. Bulgaristan Türklerinin göç konusunu konuşmasını bile yasak etti. 1969 yılına kadar göç olmayacaktı(Şimşir, 2012, s. 246-247). 
Bulgaristan'da 1955 yılından sonra Pomak, Roman ve Tatarların nüfus kayıtlarına Türk olarak yazılmalarına izin verilmedi. Bulgar Komünist Parti Merkez Komitesi'nin 1958 tarihli genel kurulunda Türkçenin konuşulmas1na sınırlamalar getirildi. Pomak, Roman ve Tatarların Türkçe eğitim görmesi engellendi. Bulgar-Türk ailelerinin çocuklarına Bulgarca isim verilmesi emredildi(Öztürk, 2012, s. 239). 1958/59 ders yılında, Türk Ortaokulları da Bulgarlaştırıldı. Türk ve Bulgar çocukları aynı sınıfta beraber ders görmeye başladılar. Türk dili yabancı dil dersi statüsüne alınarak Türk çocuklarına birkaç saat gösteriliyordu. 1960 yılında Türkçe eğitim yapan okulların Bulgarlaştırılması tamamlandı(Şimşir, 2012, s. 210) 1960'da bir anayasa ile Arnavut, Ermeni, Roman, Pomak ve Türklere Bulgar soyadı alabilme hakkı tanındı. Aynı yıl Müslüman din adamlarının mali özerkliği ortadan kaldırılarak, devletin maaşlı çalışan bir ruhban sınıfı oluşturuldu. 1968 yılında Sofya Üniversitesi'nde genelde Ortadoğu ülkelerine diplomat olarak gidecek Bulgarların eğitim gördüğü Türkoloji Programı dışında Türkçe eğitim veren hiçbir kurum kalmadı. Türkler, ülkenin etnik ve coğrafi tanımlarından çıkartıldı. Camiler bakımsızlığa terk edilirken, kadınların giydiği şalvarlara ve Müslümanların dini bayramlarına Türkiye'deki akrabaları ile iletişime geçmelerine yasaklar getirildi(Öztürk, 2012, s. 239).

Bulgaristan'da soydaşlarımızın uluslararası antlaşmalar ile elde ettikleri haklarının bir bir ellerinden alınması ve 1951 yılında birden kesilen göç dalgasının birçok Türk ailenin parçalanmasına sebep olması, Bulgaristan Türklerinin göç arzusunu kamçıladı. Bulgaristan komünist idaresi ise Türklerin bu göç isteklerine karşı olumsuz bir tavır sergilemekteydi. Bulgaristan'daki Türkler sosyalizmin kurulması için çalışmalı ve Türkiye'yi unutmalıydılar. Göç ekonomik kalkınma planını aksatabilirdi. Bulgaristan'ın olumsuz tavrı sürerken 16-21 Ağustos 1966 tarihinde Bulgaristan Dışişleri Bakanı İvan Başev Türkiye’ye bir ziyarette bulundu. Bu ziyaret esnasında göç meselesi konuşuldu. Bir anlaşmaya varılmasa da iki ülke arasında göç ile ilgili görüşmeler kesilmedi. Karşılıklı sunulan istekler ve yayınlanan bildirilerin ardından 22 Mart 1968 günü Yakın Akraba Göçü Antlaşması imzalandı(Şimşir, 2012, s. 337) Yapılan antlaşmanın ardından ilk göçmen kafilesi 8 Ekim 1969'da Edirne'ye ulaştı ve 1978 yılına kadar ülkemize 130.000 soydaşımız göç etti(Yıldırım, 2018, s. 64) 
Bulgar Komünist Parti Merkez Komitesi 1970'li yılların ortalarına doğru Türklerin Bulgarlaştırılma yöntemleri konusunda Politbüro'ya önerilerde bulunacak özel bir komite oluşturdu. Bu komite bir dizi çalışma başlattı. $\mathrm{Bu}$ çalışmaların sonucunda hazırlanan raporda Türklerin asimile edilebilmeleri için kültür seviyelerinin yükseltilmesi, Türk Azınlığı arasında sosyalist değerlerin yaygınlaştırılması, Türklerin Bulgar toplumuna entegre olmasını engelleyen dini engellerin kaldırılması gibi bir dizi önlemin alınması gerektiğinden bahsedildi. Bu kararlar Bulgaristan Komunist Partisi'nin etkili isimlerinden Georgi Atanasov tarafindan bir parti toplantısında açılandı(Dayığlu, 2005, s. 293).

Bulgaristan'da 1970 ve 1980 yılları arasında Müslümanların dini inançlarına karşı saldırılar arttı. Dini ibadetler ve ritüeller yasaklandı. Medyada İslami ritüellere geniş bir saldırı başladı. Sünnet barbarca ve pagan kültüründen kalan bir gelenek olarak tanımlanarak yasaklandı. Ramazan ayındaki orucun hastalıklara karşı bağışıklık sistemini zayıflattığı iddia edildi. Ayrıca hasat zamanına gelen oruç işçilerin performansını olumsuz etkileyerek devlete ekonomik olarak zarar veriyordu. Kurban bayramı için de yasaklar getirildi. Kısa süre içerisinde yenilen fazla miktarda et ciddi sindirim sistemi problemlerine sebep oluyordu ve çok miktarda hayvanın kesilmesi ekonomik olarak Bulgaristan'a zarar vermekteydi. Türklerin ve diğer Müslüman kadınların giymiş oldukları geleneksel kıyafetler "dinsel kıyafetler" olarak kabul edildi ve bunlara karş1 kampanyalar başlatıldı. Bu giysiler kadınların erkeklere itaatlerinin bir sembolü olarak gösterildi. Geleneksel cenaze törenleri yerine sosyalist cenaze törenlerinin yapılması istendi(Eminov, 1997, s. 206)

1984 yılına gelindiğinde Bulgar Komünist Parti İdarecileri Yeniden Doğuş (Soya Dönüş) Süreci'ni ortaya koydular. Bu süreçte Bulgar idareciler Türklerin asıllarının Bulgar olduğunu iddia etmekteydiler. Aslında bu iddialara 1970’li yıllardan itibaren kitaplarda yer verilmişti. Bulgar idareciler 1984 yılı öncesi azınlık statüsünde bulunan Pomakların ve Romanların isimlerini değiştirmişlerdi. 1948-1952, 1962-1964 ve 1971-1974 yılları arasında Müslüman Pomaklara, 1953-1954, 1965 ve 1981-1983 dönemlerinde Müslüman Romanlara, 1984 yılının yaz döneminde ise Tatarlara ve Arnavutlara Bulgar isimleri verilmişti (Atasoy, 2011, s. 100). Şimdi sıra Bulgaristan'daki Türk azınlığa gelmişti. 
Bulgar komünist idarecileri Türk azınlık için isim değiştirme kampanyalarına 1984 yılının Aralık ayında başladılar ve 24-25 Aralık 1984 ile 18 Ocak 1985 tarihleri arasındaki üç haftada Güney Bulgaristan'da (Kırcali, Haskova Bölgesi) 310.000 Türk'ün isimleri değiştirdiler(Dimitrov, 2000, s. 13). Yeniden Doğuş (Soya Dönüş) Süreci ile artık Bulgaristan'daki Türk varlığı inkar ediliyordu. Bulgaristan'da Türkçe konuşmak, Türk müziği dinlemek, şalvar gibi Türk k1yafetleri giymek, dini bayramlar, camiye gitmek, çocukları sünnet ettirmek, dügünlerde ya da cenaze törenlerinde Türklere ait olan herhangi bir geleneğin uygulanması yasaktı(Lutem, 2012, s. 145-148). Bu uygulamalar 1989 yılında resmi kayıtlara göre 345.960 soydaşımızın Türkiye'ye göçüne sebep olacaktı (Şimşir, Bulgaristan Türkleri, 2012, s. 447)

\section{Alvanlar (Yablanovo) Direnişi'nin Sebepleri}

1984-1989 yılları arasında Bulgaristan'da Yeniden Doğuş Süreci olarak tanımlanan asimilasyon sürecinde, Bulgaristan’da yaşayan soydaşlarımız ağır baskılara ve zulümlere maruz kaldılar. Bunu kabul etmek istemeyen soydaşlarımız, suçu olmaksızın cezaevlerine ya da toplama kamplarına gönderildiler. Bulgaristan'da asimilasyon kampanyalarına karşı direnişler genelde bireysel, ya da 1984 yılının Aralık ayında Kırcali ilinin bazı yerleşim yerlerinde yapılan barışçıl protesto yürüyüşleri şeklinde gerçekleşti. Alvanlar (Yablanovo) köyü Bulgaristan'da isim değiştirme kararına toplu ve örgütlü bir şekilde direniş gösteren tek yerleşim yeriydi. Alvanlılar, 17-18-19 Ocak 1985 günlerinde Gerlovo bölgesindeki diğer köylerin de desteğini alarak, üç gün boyunca isimlerinin değişmemesi ve Türk kimliklerini koruyabilmek için direndiler. Bulgaristan’da dönemin şartları göz önüne alındığında, bu direniş büyük bir cesaretle ortaya konabilecek bir eylemdi ve Alvanlıları direnişe iten sebepler son derece önemliydi. Görüşme yaptığım kişiler arasında direnişlerde aktif olarak yer alan Alvan Köybaşı isimli kişi direnmelerinin sebebini şu şekilde ifade ediyordu: " Direniş günlerinde bizim silahımız yoktu, zaten olsaydı durum başka olabilirdi. Niyetimiz öyle Bulgar Ordusu ile çatışmak da değildi. Bizim niyetimiz onları ikna etmek, ismimizi vermek istemediğimizi söylemekti. O günlerde üzerimizde zaten baskı vardı, Bulgarlar Türkçe konuşmamızı istemezlerdi. Son dönemde bizi 
çok zorlamışlardı. Biz karşı çıktık. Bir millet olmamız gerekiyormuş. Buna razı gelmedik. Alvanlar ve çevre köyler beraber direndik. Biz Türküz dedik, Bulgar olmayacağız."(Alvan Köybaşı, kişisel görüşme, 28.04.2016) Direnişte aktif rol alan ve cezaevlerinde uzun süre kalan Ali Molla ise direnişlerinin sebeplerini şöyle açıkl1yordu: "Düşündüm, ben de çok düşündüm. Ben küçüklükten beri Atatürk'ün resmine bakarak büyüdüm. Türklük, milliyetçilik sevgisiyle büyüdüm. Diğer Alvanlılar da benim gibi milletine ve inançlarına bağlıdır. Bir de söylentiler vardl, Bulgarlar köylerde kadınlara kızlara tecavüz ediyorlarmış. Biz namusumuzu ve kimliğimizi koruduk. Bunun için direndik.(Ali Molla, kişisel görüşme, 14.05.2016) O günlerde direnişin önemli liderlerinden olan köyün muhtarı Hüseyin Nuhoğlu'nun eşi Emiş Nuhoğlu da niçin direndiniz sorusuna verdiği cevapta : "Biz Bulgar isimleri almayl, Bulgar olmayl istemedik. Bizim köyümüzün eğitim seviyesi yüksekti ve insanların milliyetçi duyguları kabarlktı. Bence direnmemizin en büyük sebebi bizim diğer köylerden daha bilinçli olmamız ve cesur davranmamızdı". (Emiş Nuhoğlu, kişisel görüşme, 28.04.2016) Alvanlar direnişinin liderlerinden Ali Ormanlı da direnişlerini sebebini şöyle açıklyyordu: "Bulgarlar sadece Alevilerin, Kızılbaşların isimlerini değiştireceğiz diye söylenti çıkarmışlardı. Biz bu yüzden bir araya geldik. Kırcali'deki Türkler gönüllü oldu diye duyduk. Muhtar Hüseyin ile konuştuk. Dünya bizlere yapılan zulmü duysun diye, insanları bir araya çağırdık, direnelim istedik. Bizim köyde herkes direndi. Köyümüzdeki komünist partinin yetkilileri direnişin liderleri oldular, direnişi organize ettiler. İsimlerimizi değiştirmek benim için geçmiş ecdatlarıma ihanet etmekti. Onları inkar etmekti. Ben bunu vicdanıma kabul ettiremezdim" (Ali Ormanl1, kişisel görüşme,16.04.2016)

Alvanlıları üç gün boyunca Bulgaristan'ın en büyük zırhlı birliği olan İslimye (Sliven) zırhlı birliğine karşı direnişe iten ve onları motive eden sebep kimliklerine ve inançlarına yapılan haksız saldırılardı.

\section{Alvanlar (Yablanovo) Direnişinin İlk Günü: 17 Ocak 1985}

Bulgaristan Komünist Partisi'nin 1984 yilında Türkleri asimile etmek için başlattığı Yeniden Doğuş Süreci uygulamaları Alvanlar (Yablanovo) köyünde Aralık ayında duyulmaya başlamıştı. Alvanlar (Yablanovo) muhtarı 
olan Hüseyin Nuhoğlu bu uygulamalardan 1984 yılının Aralık ayında Güney Bulgaristan'ın Kırcali ve Haskova bölgelerinden gelen 15 civarındaki Türk aile vasıtası ile haberdar oldu. Alvanlar (Yablanovo) köyüne gelen Türk aileler açıkça isim değiştirmeye gelen Bulgar yetkililerden kaçtıkları için şehirlerini terk ettiklerini ve işsiz kaldıklarını, Alvanlara da (Yablanovo) tütün kooperatifinde çalışmak için geldiklerini söylemişlerdi (Aziz, 2004, s. 25) Bu Türk ailelerin dışında köyden gurbete gidenler de, Bulgaristan'ın diğer bölgelerinde yaşanan olaylardan köylüleri haberdar etmişlerdi. Bulgaristan'da yaşanan bu zulüm tüm soydaşlarımızı huzursuz etmekteydi. Alvanlılar da sıranın kendilerine geleceğinin farkındaydılar. Ancak bu zülüm karşısında ne yapacakları hakkında ortak bir karar henüz almamışlardı.

17 Ocak 1985'te günü sabahın ilk saatlerinde Kazan (Kotel) belediyesinden gelen bir araç Alvanlar (Yablanovo) köyündeki nüfus kütüklerini araca yükledi. Bu gelişme artık sıranın Alvanlılara geldiğinin bir kanıtıydı. Köy muhtarı Hüseyin Nuhoğlu nüfus arşivlerinin muhtarlıktan alındığı haberini alır almaz hemen harekete geçerek durumu köylülere haber vermiş ve köyün ileri gelenlerini odasına çağırarak bir danışma meclisi kurmuştu. Saat 8:30'da yaklaşık iki bin kişi köy meydanında toplanmıştı. Muhtarlığın önündeki insanlarda daha sonra yerini büyük bir cesaret dalgasına bırakacak büyük bir tedirginlik, korku ve öfke hâkimdi. Köy halkı bu olayın köyün geçmişe yönelik hafızasının silinmesi anlamına geldiğinin farkındaydı. Köydeki Türk varlığı resmi kayıtlardan siliniyordu. Bu, köy halkı tarafından kabul edilemeyecek bir durumdu. Alvanlılar meydanda varlıklarını korumak için sonuna kadar direnmeleri gerektiğini birbirlerine telkin etmeye başlamışlardı. Muhtarlık binasında yapılan görüşmeler sonunda alınan karar Bulgarların Yeniden Doğuş Süreci adı altındaki asimilasyon politikasına direniş gösterilmesi yönünde oldu. (Aziz, 2004, s. 2930). Toplantıda köye giriş çıkışların kontrol edilmesi, çevre köylerin desteğinin alınması için köylerin ziyaret edilmesi, köyde komün hayatına geçilmesi (ortak bir yaşam), köyün belli bölgelerinde nöbet yerlerinin tesis edilmesi, köy firının yirmi dört saat çalışarak hiç durmaksızın ekmek çıkarması gibi kararlar alınd. (Hasan Molla, kişisel görüşme, 29.04.2016). Alvanlar (Yablanovo) köyünde tam bir birlik söz konusuydu. Olaylara tanıklık eden kişilerle yaptığım görüş- 
melerde de herkes özellikle bu birlik ve beraberliğin altını çizdi. O güne kadar komünist parti için çalışan ve hatta halk kahramanı madalyası alan ${ }^{1}$ köylüler bile Türk kimliklerinin yok edilmesi karşısında hemşerileri ile beraber hareket ederek halka liderlik yapma ferasetini göstermişler ve bu zulmün karşısında yerlerini almışlardı.

Muhtar Hüseyin Nuhoğlu odasındaki görüşmelerden sonra Gerlovo bölgesindeki diğer köylerin desteğini almak için yola çıktı. Hüseyin Nuhoğlu ilk olarak Alvanlar (Yablanovo) köyüne üç kilometre uzaklıkta bulunan Küçükler köyüne (Malko Selo) giderek burada köyün ileri gelenlerinden Mazlum Dayı ile görüştü. Küçükler (Malko Selo) köyü de Alvanlar (Yablanovo) gibi Alevi inancına sahip Müslüman Türklerin yaşadığı bir köydü. Muhtar Hüseyin Nuhoğlu, Mazlum Dayı'ya Gerlovo bölgesinin dini lideri ve Alvanlar'da direnişin liderlerinden biri olan Dede Hasan Molla’nın gerekirse cihad ederek köylerini ve inançlarını savunacakları mesajını iletti. Mazlum Dayı bunun üzerine muhtar Hüseyin Nuhoğlu'na İslam Konferansı öncesi Türkiye'nin “Soya Dönüş Süreci'ne karşı önlem almadığını ve İslam Konferansı örgütünün de 1972 yılında Pomaklara yapılanlara karş1 göz yumduğunu belirtti. İslam konferansı örgütünün Bulgaristan'da bu yaşananlar karşısında sessiz kalırsa son çare olarak Bulgar yönetimine karşı yapılacak bir cihat ile Bulgar toprakları üzerinde yaşayan her Türk'ün kanının son damlasına kadar mücadele etmekten çekinmeyeceğini ifade etti. Hüseyin Nuhoğlu'nun Küçüklerden (Malko Selo) sonraki ikinci ziyareti Topuzlar köyüne oldu. Burada amcası Mustafa ile görüştü. Amcası onun anlattıklarından sonra bazı itirazlarda bulunsa da, derin bir inanca sahip olduğu için Dede Hasan Molla'nın iradesini kabul etti. Hüseyin Nuhoğlu Topuzlar köyünden sonra Sunni bir köy olan Doğancılar köyüne (Sokolartsi) geçerek köy muhtarı Fehim ile görüşmüş ve onların desteğini almıştı. Hüseyin Nuhoğlu'nun bundan sonraki ziyareti yine Sunni inanca sahip olan Hamzalar köyü (Filaretovo) oldu. Burada da dostu ve aynı zamanda, Bulgar Komünist Parti Sekreteri olan Mehmet ile görüşmüş ve Hamzalar (Filaretovo) köyünün de desteğini almıştı (Aziz, 2004, s. 28-33). Hüseyin Nuhoğlu'nun son durağı Karaatlar köyü (Vrani kon) oldu. Ancak

1 Komünizme yapmış olduğu hizmetlerden dolayı Halk Kahramanı madalyası ile ödüllendirilen kişi Fedail Mustafov'dur. Köyde Bay Fedail olarak bilinen bu kişi 17-18-19 Ocak günlerinde direnişe liderlik yapan kişilerden biridir. Daha sonra tutuklanmış ve yıllarca Bulgaristan hapishanelerinde yatmıştır(Hasan Ocaklı, kişisel görüşme, 16.04.2016) 
Karaatlar (Vrani kon) köyü muhtarı Alvanlara (Yablanovo) destek sözü vermedi. Karaatlar (Vrani kon) köyünün destek vermemesinin altında Bulgaristan Komünist Partisi'nin Türklerin isimlerini rahatça değiştirebilmek için onları bölme faaliyetleri yatıyordu. Karaatlar köylüleri, Sofya Komünist Parti Komitesi tarafından isim değiştirme kampanyasının sadece Alvanlar (Yablanovo) köyü ile sınırlı kalacağ1 konusunda ikna edilmişlerdi(Yücetürk, 2015, s. 54). Bulgar Komünist Parti yetkilileri bölme taktiğini diğer Sunni köylerde de denemişlerdi. 15 Ocak 1985 günü öğleden sonra Hamzalar (Filaretovo) köyünde bir yalan yayılmıştı. Hamzalar (Filaretovo) köyü muhtarı komünist parti il yöneticileri ile görüşmüş ve ona zorla Bulgarlaştırmanın sadece Alevileri kapsayacağı söylenmişti. Ancak Hamzalar (Filaretovo) köyündeki Türkler 17-18-19 Ocak günlerindeki direnişte her şeyleri ile Alvanlara (Yablanovo) destek vereceklerdi(Hasan Ocaklı, kişisel görüşme, 16.04.2016).

Hüseyin Nuhoğlu'nun çevre köyleri ziyareti esnasında Alvanlar (Yablanovo) köyünün ileri gelenleri köy meydanında köyü nasıl savunacakları hakkında görüşmeler yapmaktaydılar. Bu konuşmalara şahit olan ve direniş günlerinde aktif rol alan Ali Ormanlı bu görüşmeleri şöyle anlatmaktadır:

“Köyde nasıl direneceğimize dair farklı görüşler vardl. Bulgar Ordusu'na karşı sopa ile kazma ile direnme şansımız yoktu. Ancak hiçbir şey yapmadan da duramazdık. Tüm dünyaya neler yaşadığımızı göstermeliydik. Önerilerin bazıları hayal ürünüydü. Örneğin Bulgar Ordusu'na karşı silahla savunma yapmak, tanklar köye girerken köprüyü havaya uçurup, köy içinde silahlarla ve el bombaları atarak çarpışmak. Diğer bir öneri sessizce kaderimize razı olduğumuz izlenimini vererek, gizlice çekeceğimiz görüntü kayıtlarlyla olan biten her şeyi kayıt altına almak. Daha sonra kameralar önünde röportaj verip her şeyin zor kullanarak yapıldı̆̆ını söylemek ve görsel materyali gizlice Türkiye'deki akrabalarımız vasıtasıyla Birleşmiş Milletler Örgütü'ne ve Avrupa Insan Hakları Mahkemesi'ne göndermekti.

İlk öneri olan silahlı direniş için ne silahımız ne de mermimiz vardı. Köydeki marangoz arkadaşlar torna makineleri ile ateş edebilecek bir mekanizma imal edebilirlerdi. Ancak kaç tane silah yapabilirlerdi. Bazı gençler taş ocağından barut aşırmışlardı. ${ }^{2}$ Köydeki bazı genç delikanlılar çatışmadan

2 Hasan Özyiğit ile yaptığımız görüşmede 17 Ocak günü 90 kilo kadar dinamitin taş ocaklarından alındığını daha sonra bu dinamitlerin köyün girişindeki köprüye yerleștirildiğini ancak sağ duyunun hakim gelmesi üzerine köprüyü havaya uçurmaktan vazgeçtiklerini dile getirmiştir(Hasan Cemal Molla, kişisel görüşme, 29.04.2016). 
yanaydılar ancak onları patlayıcı kullanmaktan vazgeçirdik. İkinci öneri ise daha mantıkl gibiydi. Şunu da söylemeliyim ki; bu öneriyi sunanlar korkak değillerdi, yalnızca ileride olacaklarla ilgili rasyonel bir tutum sergilemekteydiler ve olaylara mantık çerçevesinden bakıyorlardı.

Bu konuşmalardan sonra farklı düşünsek de sonuna kadar direnmeye karar verdik. Artık evlerde oturulmayacaktı. Bulgarlaştırma sürecine direnmek için hepimiz meydanda olacaktık. Ne yaşayacaksak beraber yaşayacaktık (Aziz, 2004, s. 34-37).

Köyün ileri gelenlerinin direnişte silah kullanmama kararına rağmen köyde bazı gençler Bulgar ordusuna karşı silahlı direniş için yine de hazırlık yapıyorlardı. Bu gençlerden biri olan Ali Molla 17 Ocak günü arkadaşları ile yaptıkları konuşmalarını şu şekilde aktardı: "Ben o zamanlar 26 yaşındayım ve en deli zamanım. Arkadaşlarımı topladım ve hemen bir grup kurdum. Onlara akşam buluşacağımızı ve evlerinde bulunan silah, av tüfeği, tabanca, mermi, barut vs. ne varsa getirmelerini söyledim. Burada bir torna dükkanı vardı. Biz orada gece gündüz silah yapacaktı. Eskiden kalma tabancaları tamir ettirdim. Gece buluştuğumuzda yatakların üstüne kimde ne silah varsa attı. Karar verdik. Biz gece vakti ayrı bir grup olacă̆ız. Bulgarlar ne zaman ateş ederlerse biz de ateş edeceğiz. Ama halk ile beraber olmayacaktık biz ayrı olacaktı. Millete zarar gelmesin, gelecekse bize gelsin. Onlardan ayrılıp çatışacaktık(Ali Molla, kişisel görüşme, 14.05.2016). Ancak Ali Molla ve arkadaşları daha sonra köyün ileri gelenlerinin sözünü dinlemişler ve 19 Ocak’taki olaylarda silah kullanmamışlardı.

17 Ocak günü Alvanlar'da (Yablanovo) muhtarlık binasına Türk bayrağ1 asılarak Bulgar Komünist Partisinin asimilasyon çalışmalarına büyük bir tepki ortaya kondu(Hasan Molla, kişisel görüşme, 29.04.2016). Alvanlar (Yablanovo) muhtarlığından nüfus defterlerinin alınmasına karşı gösterilen diğer bir tepki de, bir sivil itaatsizlik örneği olarak çevre fabrikalarda çalışan köylülerin işe gitmemesi oldu(Emiş Nuhoğlu, kişisel görüşme, 28.04.2016). Alvanlıların ve çevre köylerdeki işçilerin boykotu üzerine bölgede bulunan tekstil fabrikası Müdürü Karageorgiyev ve Kazan (Kotel) Belediye Başkan Yardımcısı Krayev öğlen saatlerinde Alvanlar (Yablanovo) köyüne geldiler. Müdür Karageorgiev tekstil fabrikasında çalışan köylülerin neden işe gelmedikleri konusunda bilgi 
almak için geldiklerini, işçilerin bu yaptıklarından dolayı disipline sevk edilip işten atılacaklarını söyleyerek halkı korkutmaya çalıştı. Köy halkı adım adım ilerleyen arabanın etrafını kuşatmıştı. Köylüler: "Köyümüzün arşivleri nerede?" diye bağırıp çağırmaya başlayınca, arabadan inen Belediye Başkan Yardımcısı Kraev el kol hareketleriyle: "Yolumuzdan çekilin bize yol verin, açılmadığını taktirde sizin için kötü olacak” diyerek tehditler savurdu. Köy meydanında toplanan halk arabadan inen Karageorgiev'in ve Krayev'in arabaya tekrar binmesine izin vermedi. Ancak yolu açarak onların yaya olarak muhtarlık binasına ulaşmalarını kolaylaştırdı. Bu sırada dışarıda bulunan halkın bir kısmı muhtarlık binasına girmiş ve tepkilerini dile getirmeye başlamışlardı. Bu tehditler karşısında korkan Krayev'in savunması isim değişikliğinden haberinin olmadığını arşivlere gelince de devletin istediği zaman istediği arşivleri alabileceğini, bunun resmi bir durum olduğunu söylemek oldu. İçeride tartışmalar sürerken arabada bulunan ve bu köyde çavuş rütbesi ile görev yapan Köroğlu ile Kazan'dan (Kotel) Milis Amiri Yüzbaşı Baykov paniğe kapılarak halkın arasından kaçmaya çalışıyorlardı. Buna kızan halk arabaya zarar vermiş ancak bu iki Bulgar güvenlik görevlisi amirlerini almadan köyü terk etmeyi başarmışlardı. Arabaları giden Karageorgiev ve Kraev bir süre Alvanlar'da alıkonulmuş, daha sonra gecenin ilerleyen saatlerinde köyden gönderilmişlerdi(Hasan Ocakl1, kişisel görüşme, 16.04.2016).

17 Ocak günü köyün dini lideri olan Dede Hasan Molla (Hasan Özyiğit) köy meydanına toplanan binlerce kişiye hitaben bir konuşma yaparak, direnmeye karar veren Alvanlıların maneviyatını güçlendirdi. Hasan Molla konuşmasında, Alvanlar (Yablanovo) köyünde yaşayanların geçmişinden bahsederek kendilerinin saf Türk olduklarını, Bulgarların yalan attıklarını, eğer birlikte hareket ederlerse hiç kimsenin Türklerin isimlerini değiştiremeyeceğini, güçlü rüzgarların bir ağacın dallarını kırabileceğini ancak hiçbir zaman kökünden sökemeyeceğini dile getirmişti. Hasan Molla yaptığı bu konuşma ile halkı cesaretlendirerek birlik çağrısında bulunmuştu(Hasan Molla, kişisel görüşme, 29.04.2016).

Alvanlar (Yablanovo) köyünde ertesi sabah Hüseyin Nuhoğlu'nun başkanlık yaptığı toplantı sonucunda dini lider Hasan Molla'nın tavsiyesi ile köyde 
komün hayatı başlatıldı. Köy fırını ücretsiz ekmek dağıtırken devletin bütün imkanları seferber edilip halkın hizmetine sunuluyordu (Aziz, 2004, s. 53-54). 17 Ocak gecesi köyün girişlerine nöbetçiler kondu. Köy meydanında ve bazı yerlerde büyük ateşler yakıldı. Hava çok soğuktu ve herkes yanan ateşin yanında 1sınmaya çalışıyordu. Bir tehlike anında sirenlerin çalmasına ve herkesin toplanmasına karar verildi. Herkeste büyük bir heyecan ve tedirginlik vardı. 17 Ocak günü köy meydanında bulunan Hasan Ocakl1: “Köyün merkezinde büyük ateşler yükseliyordu ve etraflarında ısınan insanlar vardı. Birileri gidiyor ve başka birileri geliyordu. Konuşmalar, yorumlar, umutlu ve umutsuz bekleyişler sürüp gidiyordu. Ellerde portatif denilen küçük radyo alıcıları vardı. Türkiye'den bir ses bekleniyordu. Ana vatan ise susuyordu. Birileri Turgut Özal'ın konuşmasını bekliyordu. Ama Turgut Özal konuşmamıştı. "Hür Avrupa" veya 'BBC" radyoları ara sıra birşeyler mırıldanıyordu... Ama Bulgarların bunları da engellediği söyleniyordu” (Hasan Ocakll, kişisel görüşme, 16.04.2016) Yine o gecenin tanıklarından Emiş Nuhoğlu: "Halkta korku vardı. Ama aynı zamanda büyük de bir cesaret vard. Direneceğiz ve isimlerimizin değişmesini engelleyeceğiz. Biz Bulgar değiliz, biz Türküz. Tanklara silahlara karşı herkesin elinde sopa, balta, düveni gibi şeyler bulunuyordu"(Emiş Nuhoğlu, kişisel görüşme, 28.04.2016) O gecenin diğer bir tanığ1 Mustafa Cafer Marhem'in 17 Ocak gecesinden hatırladığ1 : "Tetikteydik. . Insanlarl uyku tutmuyordu, hepimiz çok tedirgindik. Büyük bir korku vardı. Acaba ne olacaktı? Duyduk ki Klrcali tarafinda Mestanlı'da insan öldürmüşler. Insanların kafalarında çeşitli düşünceler vardı. Acaba aynısı bizimde başımıza gelecek miydi? Ancak ne olursa olsun ismimizi değiştirmeyi kabullenemedik, kimse kabullenmedi. Ne olacaksa olacaktı” (Mustafa Cafer Marhem, kişisel görüşme, 14.05.2016)

17 Ocak gecesi isim değiştirmeleri önlemek için bulunan çarelerden biri de Alvanlıların ve çevre köylerin Türk olduklarını ve isimlerini değiştirmek istemediklerini belirten dilekçelerin yazılarak Sofya'ya Bulgaristan Komünist Partisi Merkez komitesine götürülmesi oldu. 17 Ocak gecesinde yazılan dilekçeler sabaha karşı yola çıkartıldı. 18 Ocak günü de Sofya' da teslim edildi. Ancak bu girişim de sonuçsuz kalacaktı. Dilekçeleri Sofya’ya götürenler 18 Ocak gecesi dönüş yolunda Osmanpazarı (Omurtag) civarlarında tutuklanarak, ilçe 
merkezine götürüldü ve saatlerce nezarethanede yapılan zulümden sonra isim değişikliğine uğradılar(Yücetürk, 2015, s. 60).

\section{Alvanlar (Yablanovo) Direnişinin İkinci Günü: 18 Ocak 1985}

Alvanlılar ve destek için gelen tüm Gerlovo halkı 17 Ocak gecesini köyün belirli bölgelerinde yakılan büyük ateşlerin çevresinde geçirmişlerdi. 18 Ocak sabahı erken saatlerde köyde sinemacı Cafer'in sorumlu olduğu sirenlerin sesleri yankılanmaya başladı. Alvanlardaki (Yablanovo) soydaşlarımız isimlerini değiştirmek için baskıya gelen Bulgar emniyet güçleri ve komünist parti yöneticilerinin oluşturduğu konvoy Küçükler Köyü yönünden Alvanlara (Yablanovo) doğru yaklaşmaktaydi. Siren sesleri ile birlikte halk büyük bir heyecana kapılarak önce köy meydanına sonra da konvoyun geldiği yola doğru koşuşturmaya başladı. Köye gelen konvoy muhtarlığa 300 metre kala Emiroğlu Pastanesi'nin önünde durduruldu(Hasan Ocakl1, kişisel görüşme, 16.04.2016). Bulgar askeri konvoyu beş otobüs, dört askeri kamyon, bir adet itfaiye aracı ve içinde milislerin bulunduğu askeri bir araçtan oluşuyordu (Aziz, 2004, s. 71). Askeri konvoyun komutanı Parti Sekreteri Bonçev yolu kapatan halktan yolun açılmasını istedi. Ancak Alvanlılar konvoyun önüne etten bir duvar örmüşler ve Bonçev'in tehditlerine kulaklarını tıkamışlardı. Halk her şeyi göze alarak geri çekilmiyordu. Bulgar yetkililer ilerleyemeyeceklerini anlayınca görüşmek için Alvanlar köyü muhtarı Hüseyin Nuhoğlu'nu konvoya çağırdılar. Hüseyin Nuhoğlu ile görüşen askeri konvoy, köylülerin ve idarecilerin geri çekilmeye niyetleri olmadığını görünce Alvanlar'1 terk etmeye karar verdi(Rukiye Ahmedova Köybaş1, kişisel görüşme, 28.04.2016) Alvanlılar 18 Ocak günü direnerek Bulgar emniyet güçlerinin isimlerini değiştirmesini engellemişlerdi. Bulgar yetkililer geri dönmelerine rağmen, o gün kendilerine direnen halka liderlik edenleri kameraları ile kayıt altına aldılar. Bu kayıtlar 19 Ocak günü direnişte aktif rol alan kahramanların tutuklamasında kullanılacaktı. 18 Ocak günü direnenler arasında bulunan Ali Ormanlı o günü şöyle aktarıyordu: “18 Ocak günü iki unutulmaz anım var. İlki köyümüzdeki tek Bulgar ailesi olan Bonka teyze ve Bay Yonko ellerinde değnekler ile bizlere destek vermek için meydana geldiler ve bizimle direndiler. İkinci anım ise kardeşim Mehmet Ormanlı'nın kızı, 7 veya 8. Sınıf talebesi olan Ayten'in bir yolunu bulup tankın üzerine çıkarak coşkulu 
şekilde "Abluka” şiirini okumasıdır. Ayten'in şiirini askerler ve Bulgar özel kuvvetleri kızıl bereliler de alkışladılar. Şiiri okuduktan sonra bir Bulgar subayı ona sarllarak tankin üstünden indirdi ve babasina teslim etti."(Ali Ormanl1, kişisel görüşme, 16.04.2016)

18 Ocak gününden sonra geri çekilen Bulgar güçlerinin tekrar daha güçlü bir şekilde geri döneceklerini tahmin eden Alvanlılar o gece köyde belirlenen nöbet yerlerini güçlendirdiler. Bir numaralı nöbet yeri Şumnu'dan gelebilecek bir askeri birliğe karşı Hasan Pehlivan'ın evine yakın bir yerde konumland1rılmıştı. İkinci nöbet yeri Kazan (Kotel) tarafından gelebilecek askeri bir güce karşı belirlenmişti. Buraya $10 \mathrm{~mm}$ kalınlığında 40 metre uzunluğunda bir inşaat demiri kondu. Demirin üzerine bir kamyon mıcır döküldü. Dökülen mıcır soğuğun etkisiyle donmuş ve bir nevi basit bir set inşa edilmişti. Üç numaralı nöbet yeri ise köyün merkezine inşa edilmişti. Görevi bir ve iki numaralı nöbet yerlerinin ihtiyaç anında yardım etmek, koordinasyonu sağlamaktı. 18 Ocak gecesi soğuk dayanılmaz şekilde isırıyordu, bu yüzden tarım-sanayi kooperatifinde ne kadar kullanım dışı kamyon ve motorlu taşıt lastiği varsa büyük çaplı ateşleri beslemek için kullanıldı (Aziz, 2004, s. 92-93).

\section{Alvanlar Direnişinin Üçüncü Günü: 19 Ocak 1985}

Bulgar emniyet güçleri 18 Ocak günü Alvanlar'daki geri çekilmenin ardından Bulgaristan'ın en büyük zırhlı birliği olan İslimye (Sliven) zırhlı birliğinin desteğini alarak, 19 Ocak günü daha güneş doğmadan Alvanlar'daki kahramanların direnişini kırmak için yola çıkmıştı. Zırhlı birlikler sabah saat 04:30 sularında Hamzalar (Filaretovo) köyüne ulaştı. Askeri konvoyun üzerinde bir helikopter de vardı. İl ve ilçe komünist parti ve devlet yöneticileri askeri üniformalar içindeydi. Hamzalar (Filaretovo) köyünde siren sesleri yankılanıyordu. Hamzalar (Filaretovo) köyü halkı siren sesi ile birlikte köyün girişindeki boğaza koştu ve askeri birlikler ile karşı karşıya geldi. Bulgar askeri güçleri komutanı İl Emniyet Müdürü General Ganev insanların yolu açmasını istedi. Ancak hiç kimse yerinden kipırdamad. Daha sonra İl Komünist Partisi Birinci Sekreteri Veliçko Petrov soydaşlarımız ile alay edercesine "Bu gün sizin en büyük bayramınız. Tekrar köklerinize dönüyorsunuz. Yolu açın. Biz kararlıyız. Ne olursa olsun geçeceğiz" dedi. Ancak insanlar bu tehditlere rağmen korkmadı ve kimse 
yerini terk etmedi. Bunun üzerine General Ganev tanklara hareket emri verdi. Tankların birden hareket etmesiyle İbrahim Çetin elleriyle dayandığı tankın paletleri altında kaldı ve orada şehit düştü. Bunu gören insanlarda bir panik başladı ve yol açıldı(Mutlu, 2014, s. 97-98).

Bulgar zırhlı birliği Hamzalar köyünden sonra 19 Ocak sabahı saat 5'de Küçükler (Malko Selo) köyüne ulaşmışlardı. Zırhlı birlikler sık sık durduruluyor, askerler ellerindeki aletler ile yol üstlerini veya köprülerin altlarını herhangi bir bomba tuzağına karşı tarıyorlardı. Küçükler (Malko Selo) köyünü geçen birlik sabah sat 06:00'da Alvanların (Yablanovo) girişine ulaştı. Alvanlarda (Yablanovo) saat 05:30'dan beri sirenler çalmaktaydı. Halk kısa süre içinde bir gün önce demir çubuk gererek inşa ettikleri Kazan (Kotel) yolundaki küçük setin arkasında toplandı. En önde kadınlar ve çocuklar, arkalarında gençler ve en arkada ise yetişkin erkekler sıralanıyordu(Ali Ormanl1, kişisel görüşme, 16.04.2016). Kadınlar ellerinde bir gece öncesinde yaptıkları bez bebekler tutuyorlardı ve tankların ilerlemesini engellemek için bu bez bebekleri sanki gerçekmişçesine tankların paletleri önüne attılar (Alvan Köybaşı, kişisel görüşme, 28.04.2016). Bulgar askeri birliğinin komutanı General Ganev direnmeye kararlı Alvanlılara yüksek sesle geri çekilmelerini emretti. Ancak hiç kimse yerinden kıpırdamadı. Tanklar halkın üzerine doğru geliyor halk geri çekilmeyince şaha kalkıyorlar ve etrafı motor homurtaları kaplıyordu. Ancak hiç kimsede bir korku belirtisi yoktu. Bunun üzerine General Ganev Alvanlılar'dan bir heyet belirlemelerini istedi. Köyün Komünist Parti Sekreteri Hasan Berberov, köyün muhtarı Hüseyin Nuhoğlu ve köyün ileri gelenlerinden Fedail Mustafov Alvanlıları, temsilen General Ganev ile görüşmek için askeri birliğe doğru yöneldi. General Ganev ilk iş olarak Fedail Mustafov'u tevkif ettirdi. Arkasından askeri birlikler sis ve göz yaşartıcı bombaları halka doğru atmaya başladılar. Alvanlılar da kendilerine atılan sis bombalarını yerden alarak geri atıoorlardı. Ganev askerlere ilerleme emrini verdi. Bu emirle birlikte Bulgar askerleri havaya ateş etmeye başladılar. Her yer bir anda savaş alanına döndü. Tanklar yoldan ayrılarak köylülerin avlularına, bahçelerine girdiler, çitleri yıktılar ve kalabalığın içine girerek onları dağıtmaya başladılar(Hasan Ocaklı, kişisel görüşme,16.04.2016) Tankların arkasından köye giren itfaiye araçları dondurucu soğukta insanların üzerine yağlı 
bir sıvı sıkmaya başladılar. Tankların ve itfaiyenin arkasından Bulgar emniyet güçleri halkın arasına daldılar ve kadın, çocuk, ihtiyar demeden dövmeye yerlerde sürüklemeye başladılar. Alvanlar'da (Yablanovo) tam bir can pazarı yaşanıyordu. Halk tankı, tüfeği ile gelen Bulgar ordusu karşısında dağılmıştı. 19 Ocak günü direnişe katılan ve tutuklanan Mustafa Cafer Marhem yaşadıklarını şöyle dile getiriyordu:

"19 Ocak'ta yollarda köyün girişindeydik. Sabaha karşı tanklar belirince bütün köylü toplandı. Saat 5:30 muydu 6:00 mıydı neydi. Tankların ışıklarını Küçükler köyünden gelirken gördük. Tankların sayısını bilmiyorum o kadar çok tank vardı ki, uzaktan bile biz konvoyun sonunu göremedik. Helikopterinde olduğunu söylediler. Ben görmedim. Bir de bu dağların arkasına Bulgar özel harekât birlikleri indirilmiş. Yani biz tankları köye sokmazsak, dağdan özel kuvvetler köyümüze girecekti. Bulgaristan'ın en büyük zırhlı birliği bizim İslimye (Sliven) birliğidir. Bütün İslimye'nin (Sliven) zırhlı araçlarını getirdiler. Bizim ise saldırdıklarında onlara zarar verebilecek hiçbir silahımız yoktu. Çoğumuzun cebinde çakı bile yoktu. Şimdi düşünüyor musunuz, ellerinde hiçbir şey olmayan insanların üzerine tanklarla geliyorlar. O gün köyün girişinde asfaltın önünde bir kordon olduk. Geçemediler, o zaman tanklar etraftan insanların avlularından köye girdiler. Insanların üzerine sürmediler. İtfaiye arabaları köye girdi ve insanların üzerine su sıkmaya başladılar. Halkı dağıttılar. Insanlar kaçıyor, silahlar çatırdıyordu. Kalaşnikoflarla sağa sola ateş etmeye başlamışlardl. Asker çok sert davrandl. Kimi yakaladıysa coplarla dövdü. Kadın, uşak, yaşlı hiç bakmadılar. Zaten 7 den 70 'e kadar herkes oradaydl. Sirenler çalınca etraf köyler de gelmişti. Küçükler, Doğancllar, Rahmanlar ve diğerleri. Askerler insanları dövmeye başlayınca kendimizi kurtarmak için evlerimize kaçtık. Zaten sırılsıklam olmuştuk. Hava eksi 20, 25 derece vardı. Zaten üstündeki urbanı değiştirmen lazımdı. Onlarda bunu firsat bildiler ve başladılar ev ev gezmeye. Yollarda tanklar geziyorlardt."(Mustafa Cafer Marhem, kişisel görüşme, 14.05.2016). 19 Ocak günü direnişe katılan Cumaziye Yıldız'da o günü şöyle anımsıyordu: "Bulgarlar 18 Ocak'ta geri çekilirken, siz teslim olmuyorsunuz. O zaman yarın bekleyin dediler ve gittiler. 19 Ocak'ta tankları tüfekleri ile geldiler. Biz köy meydanında sabahlamıştık. O gün nereden gürültü koparsa o tarafa gidiyorduk. En son aşağıya köyün girişine gittik ve karar verdik, oradan kafiri salmayacağız. Kazan (Kotel) tarafindan geldiler. Bulgar isimlerini almak istemiyoruz diyoruz. Onlar bizi ikna etmeye çalışıyorlardı. Biz bir ağızdan bağırıyoruz. Biz Türküz, isimlerimizi değiştirmeyin. Komşudan bir battaniye istedik, yapma birkaç tane bebek 
yaptık ve tankın önüne koyduk. Tanklar büyük gürültüler çıkardılar. Tanklardan boşa bombalar attılar. Büyük gürültüler koptu. Tanklar biz çekilmeyince köyün kenarındaki avluya girdiler, ağaçları yıktılar, insanların ardına düştüler. Ondan sonra başladılar panzerler su atmaya. Herkes kaçışmaya başladı. Bende köyüme doğru yola çıktım. Babamın küçük baltasını alıp, paltomun içine koymuştum. Sadece sapı gözüküyordu. Evimizde ne bulursak almıştık. Ancak kalaşnikofa, tanka karşı çakının sopanın gücü ne? "(Turgut yıldız ve Cumaziye Yıldız, kişisel görüşme, 29.04.2016)

Sabah saat 09:30’da köy meydanındaki tablo şöyleydi; dört adet tank namlularını bir yöne çevirip kare oluşturacak şekilde pozisyon almıştı ve o karenin içinde sayısız Alvanlı vardı. Yine aynı şekilde dört tank daha ve aralarında insanlar vardı. Beş-altı adet kamyon halka oluşsturacak şekilde dizilmiş, içinde insanları toplamıştı. Ve böyle altı binin üzerinde insan meydanda çevrelenmişti. İnsanların üzerinde helikopter uçuyor, kameralar kayıt alıyorlard1. Sivil ve askeri üniformalı emniyet güçleri ile kırmızı bereliler dediğimiz özel kuvvetler kalabalığın içinden önceki gün çektikleri fotoğraflara bakarak direnişe önderlik edenleri tespit edip, tutuklayıp, öledüresiye dövüyorlardı. Bir taraftan insanlar tutuklanıp dövülürken diğer taraftan İslimye (Sliven) ili Komünist Parti Sekreteri Veliçko Petrov Alvanlı halkına sesleniyordu: “ Sizlerin ataları Bulgar idi... Onları Osmanlı, kılıcın gücü ile Türkleştirdi... ve İslamlaştırdı... Türkler sizlerin üzerinde soykırım işlediler... Yıllar geçse de alnınızdan bu kara lekeyi temizlemeliydik. Bizler bugün bunun için buradayız. Adlarınızı geri vereceğiz... Güzel Bulgar adlarınızı... Atalarınızın kutsal adlarını... Biz sizlerin kurtarıcısıyız. Fakat,bir avuç Türk milliyetçisi sizlerin kafalarınızı karıştırıp partinin ve devletin bu kararını kösteklemeye çalıştılar... Amaçlarına ulaşamadılar ve hiç bir zaman da başaramayacaklar. Çünkü bizler güçlüyüz ve ne pahasına olursa olsun biz bu kutsal davamızdan bir adım bile geri atmayacağız. Türk milliyetçilerinin hedefleri taşlara çarpacaktır. Aynı taşlarla da biz onların kafalarına vuracağız... Sözlerime herkes inansın ki tarihi bir haksızlık bundan sonra tarih oluyor... Herkes evine gidecek. Eski pasaportunu alıp muhtarlığa götürecek. Yeni güzel bir Bulgar adını seçip yeni kimliğini alacak..." (Hasan Ocaklı, kişisel görüşme, 16.04.2016)

19 Ocak günü Alvanlar'da (Yablanovo) büyük bir kahramanlık destanı 
yazılmıştı. Komünizm ile yönetilen bir ülkede bir avuç soydaşımız Türk kimlikleri ve inançları için ellerinde hiç bir savunma aracı olmaksızın komünist partinin aldığ gelenleri tutuklandı, işkencelere uğradı ve toplama kamplarına atılıp sürgünlere gönderildi.

\section{Direniş Sonrası Tutuklamalar ve Alvanlar'da (Yablanovo) Yaşananlar}

19 Ocak'ta İslimye (Sliven) zırhlı birliğinin takviyesi ile köye giren Bulgar komünist idarecileri ve emniyet güçleri halka evlerine gitmelerini ve kimliklerini alarak köyün muhtarlık binasına gelmelerini emretmişti. Direnişte aktif rol oynayanlar ise Bulgar emniyet mensupları tarafından tespit edilerek tutuklanmaya ${ }^{3}$ başlanmıştı. Bu tutuklamalar esnasında Bulgar emniyet mensupları soydaşlarımıza çok sert davranmakta ve büyük eziyetler etmekteydi. Alvanlar'da (Yablanovo) tutuklanan kişiler İslimye'de (Sliven) emniyete götürülüyor, burada sorgulandıktan ve dövüldükten sonra İslimye (Sliven) emniyetine ait olan garajlardaki hücrelere kapatılıyordu. Tutuklanan soydaşlarımız, devlete ihanet, Türkiye adına casusluk, terör, örgütlü bir şekilde Bulgaristan devletini yıkmaya çalışmak gibi suçlamalar ile karşı karşıyaydılar (Ali Molla, kişisel görüşme, 14.05.2016) Direniş günlerinden sonra tutuklanan soydaşlarımızın yaşadıkları korkunçtu. O gün tutuklananlardan Ali Ormanlı:

"Ben eve gelince üç polis evime gelerek beni muhtarlığa çağırdılar. Ben daha salona girer girmez bana bağırdılar: Kaldır ellerini, sırtını duvara dön, bacaklarını genişlet! Ben bunları yaptıktan sonra bana vurmaya başladılar, gözdağı vermek istiyorlardl. Salona baktım bütün duvarlarda tevkif edilen köydeşlerim, yüzleri duvarlara doğru, duvardan bir metre kadar mesafede, ayakları ve bacakları açık vaziyette, vücut ağırlıklarını ayak parmakları üzerine kaldırmışlar, tek baş ve işaret parmakları ile duvarlara dayanmışlardı. Askerler ayrı ayrı herkesin vücudunu elleyerek arama tarama yaptılar. Beni

\footnotetext{
3 17-18-19 Ocak günleri Alvanlar'da direniște aktif rol alarak tutuklanan ve Belene toplama kampında tutuklu kalan soydaşlarımızın sayısı 24 farklı siyasi mahpushanelerde ise tutuklu kalan soydaşlarımızın saysı 17'dir..Belene'de Tutuklu Kalan Soydaşlarımızın Listesi: Ali Ormanlı, Ali Önder, Ahmet Yılmaz, Ahmet Karaca, Ahmet Mahremoğlu, Alvanköybaşı, Hasan Ocaklı (Küçükler), Hasan Çavuş, Hasan Dönmez, Hasan Çetin, Hasan Durali, Halil Karagözoğlu, Hüseyin Beyzatoğlu, İbrahim İslam, İbrahim Güdüloğlu, İsmail Alicikoğlu, İsmail Ulubey, İsmet Balkanlı (Hamzalar), Mehmet İdrizoğlu, Mustafa Mahremoğlu, Nuh Nuhoğlu, Nasuf Bilal (Doğancilar), Osman Mahremoğlu, İbrahim Çetin(Hamzalar) Siyasi Mahpushanelerde Tutuklu Kalan Soydaşlarımızın Listesi:Ali Cambzoğlu, Ali Karaca, Ali İmamoğlu (Hamzalar), Cumaziye Cambazoğlu, Fedail Koca-İbrahimoğlu, Hasan Berberoğlu, Hasan Molla, Hüseyin Nuhoğlu, Halil Yamankaya, Mehmet Kara-Ali, Mustafa Kara-Ali, Mustafa Bilal (Doğancılar), Mustafa Musaoğlu, Osman Hüsemoğlu, Süleyman Bayramoğlu, Turgut Cambazoğlu (Yücetürk, 2015, s. 376).
} 
sonra kapalı bir arabaya bindirdiler. Bizi İslimye'ye (Sliven) polis dairesine oradan da garajlara götürdüler. Orada otuz yedi gün kaldım, çok soğuktu. Isınmak için birbirimize sokulurduk. Bizi çıplak soyup döverlerdi. Ben üç numaralı odada 15-20 kişi ile birlikte kaldım. Derece sıfirın altında 28 idi. Hücreye bırakılan su bile donmuştu. Beton zemin rutubetliydi ve sık sık donuyordu. Sorgulara üç kişi giriyor, ikisi sağımda ve solumda farkl farkl sorular soruyorlardl. Arkamda da biri vardı ve o sadece sanki senin üstüne atlayacakmış gibi homurtu çıkarıyordu. Beni korkutup şaşırtmak istediklerini düşünüyorum. Sorgularda bana hayatta unuttuğum şeyleri bile sordular. Hayat boyunca yaptığım her şeyi fişlemişlerdi ve dosyamdan çıkarıyorlardı. Mesela benim ögretmen okulunda okurken, onların kahramanı olan Georgi Dimitrov için tören vardl. Ayakta durmaktan ayaklarım ă̆ııdı. Bir arkadaşım törenden çıkalım ve okula dönelim dedi. Bu olayı siyasi bir suç olarak kabul ettiler ve dosyama koydular. Beni 19 Ocak'tan, 2 Mart 1985'e kadar Islimye'de (Sliven) tuttular. Daha sonra Belene Toplama Kampı'na gönderdiler" (Ali Ormanl1, kişisel görüşme, 16.04.2016)

19 Ocak günü tutuklanan Mustafa Cafer Marhem İslimye'deki (Sliven) hücrelerdeki hayat şartlarını şöyle anlatıyordu: "Odada bir ampul var, ısınma diye bir şey yok. Buz gibi duvarlar şapır şapır terliyor. Şubat ayı. Yemek günde yarım dilim ekmek verirler ve üzerine yarım kaşık ketçap ya da mayonez koyarlardı. Öğlen ve akşam aynıydı. Sabah öğle akşam tuvalete çıkarırlardı. Duş hiç almadık. Orada koğuşta bir huzursuzluk olursa yine dayak olurdu. Bizim kaldığımız yer ile sorgulandı̆̆ımız yer ayrıydı. İkisi arasında $5 \mathrm{~km}$ kadar vardı. Cezaevinde kalır, emniyette sorgulanırdık. Illk günlerde her gün sorgu olurdu. Sonra haftada bir olmaya başladi. Biz Belene'ye gidince dedik ki cennete geldik. Oraya gelene kadar hiç güneş görmedik. Arabadan inince güneşi gördük bize cennet gibi geldi. Dedik dünya var” (Mustafa Cafer Marhem, kişisel görüşme,14.05.2016) Alvanların dini lideri olan Hasan Molla da tutuklanarak İslimye'deki (Sliven) işkencelerden nasibini almıştı: "Olaylar yaşandı eve gittim. Beni aynı gün tutukladılar ve evde arama yaptılar. Kelepçeyi taktılar ve beni tekme tokat muhtarlı̆̆a götürdüler. Köyden hemen hemen herkesi aldılar. Köy meydanında yaptığım konuşmayı kayda almışlar. Ben itiraz ettim. Beni ormana götürdüler. Garaj dedikleri yerde hücrede kaldım. Küçücük bir yer. Odada 15-20 kişi vardık. Bir tane battaniye verdiler, onunla ayağını örtemezsin. Çok soğuktu. Uyku uyuyamazsın. Günde bir defa yemek yediysem dört defa sopa 
yedim. Sabah iki dilim ekmek, bir kaşık salça birazcık da peynir verirlerdi. $\ddot{O} \breve{g}$ len ve akşam da aynı şeyi veriyorlardı. Sorgularda halkın önünde ne konuştun diye sordular. Dayak istemediğin kadardı. Ben öleceğimi düşünerek vasiyet bile ettim. Burnum kırık, kulak zarım patlamış, çenelerim dağılmıştı. Tuvalete giderdim, hep kan vardı dayaktan. Her gün dövdüler beni. Bana idam cezası verdiler. Ben 269. maddeden sorgulandım. Devlete karşı gelmek, örgüt liderliği ve devlete karşı silahla direniş yapmaktan.(Hasan Molla, kişisel görüşme, 29.04.2016).

Alvanlar (Yablanovo) direnişine katılmak için çevre köylerden gelen soydaşlarımızda 19 Ocak’ta Bulgar askeri birliklerinin köye girmesinden sonra Alvanlar'1 terk ederken köy yollarında yakalanıp tutuklandılar. Tutuklu bazı soydaşlarımız askerler tarafından ağaçlara bağlanmışlar, daha sonra otobüsler ile İslimye'ye (Sliven) götürülmüşlerdi(Turgut Yıldız, kişisel görüşme, 29.04.2016).

Alvanlarda (Yablanovo) yapılan tutuklamaların ardından bir yıla yakın köyde hayat normale dönmedi. Bulgar askerleri köyden ayrılmayarak evlerde sık sık aramalar yaptı. İnsanları huzursuz etmeye devam ettiler(Hatice İslam, kişisel görüşme, 28.04.2016) Köyde kadınların şalvar giymesi yasaktı. Eğer bir kadın şalvarla görülürse para cezası kesiliyordu. Türkçe yazmak ve konuşmak da yasaklanmıştı(Elif Özyiğit, kişisel görüşme, 29.04.2016) Alvanlar'da (Yablanovo) herkes Bulgar isimlerini yazdığı yaka kartları takmak zorundaydı. Yakınları tutuklananlar çok zor şartlar altında yaşıyorlardı. Bulgar güvenlik güçleri tutukluları ailelerine göstermiyorlar ve durumları hakkında da hiç kimseye bilgi vermiyorlardı. Bu da aileler üzerinde korkunç bir tedirginlik ve üzüntüye sebep oluyordu(Duranca Ormanll, kişisel görüşme, 16.04.2016) Uzun yıllar boyunca Alvanlılar yaşadıkları baskıları unutamamışlar, psikolojik travmalar ve sosyal yaralar ile baş başa kalmışlardı. İsim değiştirme olaylarından iki yıl gibi kısa bir zamandan sonra 5000 kişilik Alvanlar (Yablanovo) köyünden 330 kişi hayatını kaybetti (Atasoy, Bizden Olan Ötekiler, Asimilasyon Kıskacında Bulgaristan Türkleri, 2011, s. 115) Alvanlarda yaşayan soydaşlarımız akrabalarının nerelerde tutuklu olduklarını aylar sonra öğrendiklerinde bir nebze de olsa rahatlayabildiler. Bulgar emniyet güçleri olaylar yaşandıktan sonra köyün giriş ve 
çıkışlarında kontrol noktaları kurdular ve köye kimsenin girmesine izin vermediler. Yaklaşık bir ay sonra bölgede yaşanan olaylar hakkında bilgi almak için Alvanlara (Yablanovo) gelen Amerikan elçilik memurlarına köyün girişinde nöbet tutan milisler çok dikkatli olmaları aksi takdirde ateş edecekleri uyarısında bulunuyorlardı(F.C.O. 28/6744, No:74). Ancak dünya bir demir perde ülkesi olan Bulgaristan'ın Garlevo bölgesinde yaşanan bu kahramanlık hikayesinden habersizdi. Alvanların (Yablanovo) direnişi ile ilgili ilk haber 1 Mart 1985'de Sunday Times gazetesinde çıktı ve Alvanlar (Yablanovo) köyünde kanlı olayların yaşandığı tüm dünyaya duyuruldu(F.C.O. 28/6744, No:245/1) Türkiye ise Alvanlar'da (Yablanovo) yaşanan bu direnişi Güneş Gazetesinin, 28 Şubat 1985 günü Sunday Times'dan aldığı yazıyı sütunlarına taşıması ile öğrendi. (Şimşir, 1985, s. 210).

\section{Sonuç}

1984-1989 yılları arasında Bulgaristan'daki soydaşlarımıza uygulanan asimile süreci Bulgar milliyetçilerinin homojen bir ulus oluşturma hedefindeki son hamlesiydi. 1984 öncesinde ülkede Türk azınlığı kadar çok nüfusa sahip olmayan Makedon, Ulah, Pomak ve Roman azınlıklar asimile edilmiş ve isimleri Bulgar isimleri ile değiştirilmişti. 1984 Aralık ayında sıra Bulgaristan nüfusunun yaklaşık \%10'unu oluşturan Türk azınlığına geldi. Bulgar Komünist Parti yöneticileri Türk köylerini basmaya ve Türklerin isimlerini zorla değiştirmeye başladılar. İsim değiştirme baskısına direnen Türkler, çoğu zaman yargılanmadan cezalandırıldılar. Cezaevlerine ve toplama kamplarına gönderildiler. Güney Bulgaristan'da isim değiştirmeler tamamlandıktan sonra, Bulgar Komünist Parti yetkilileri ülkenin diğer bölgelerindeki Türklerin isimlerini değiş̧irmeye başladılar.

1985 yılının Ocak ayında Bulgaristan Komünist Partisi idarecileri Kuzeydoğu Bulgaristan'daki İslimye (Sliven) iline bağlı Kazan (Kotel) ilçesinin Alvanlar (Yablanovo) köyünde yaşayan soydaşlarımızın isimlerini değiştirmek için harekete geçtiler. 17 Ocak’ta köye gelen Kazan (Kotel) Belediyesi memurları köyün nüfus defterlerini Alvanlar (Yablanovo) köyündeki hiçbir görevliye haber vermeden aldılar. Yaşanan bu olay köyde büyük bir tepkiye sebep oldu. 
Alvanlılar nüfus defterlerinin alınmasının köydeki Türk izlerini silmek için yapılan ilk hamle olduğunun farkındaydılar. Aynı gün köy meydanında toplanan halk, toplu bir şekilde hareket ederek kimliklerini ve isimlerini korumak için birlikte mücadele etmeye karar verdi. Gerlovo bölgesindeki diğer köylerin de desteği ile Alvanlılar 18 Ocak günü köylerine gelen Bulgar askeri konvoyunu köye sokmayarak, ülkede Yeniden Doğuş Süreci'ne karşı koyan ve toplu bir direniş gösteren ilk ve tek yerleşim yeri oldular. 17 Ocak'ta ve 18 Ocak'ta Alvanlar (Yablanovo) köyüne giremeyen Bulgar emniyet güçleri ve komünist yetkililer, 19 Ocak’ta Sliven Zırhlı Birliği'nin desteğiyle Alvanlara (Yablanovo) girdiler. Köyde kontrolü eline geçiren Bulgar ordusu, Alvanlarda (Yablanovo) halkı direniş için cesaretlendirenleri ve onlara liderlik yapanları tutukladı. Tutuklanan Alvanlılar Bulgaristan'ın çeşitli cezaevlerinde ve toplama kamplarında yıllarca işkence gördüler.17-18-19 Ocak günlerinde ellerindeki taş ve sopalarla Bulgar ordusunun tanklarına karşı kimliklerini ve isimlerini korumak için mücadeleyi göze alan Alvanlılar, Bulgaristan Türkleri Tarihi'ndeki yerlerini aldılar. 


\section{Kaynakça}

\section{Arşiv Belgeleri}

The National Archives

Foreign Commonwealth Office (FCO), 28/6744, No:74, F.C.O. 28/6744, No:245/1

\section{Eserler}

Ahmed, Şaban (2012). Bulgaristan'da Alevilik (Yablonovo Örneği). İstanbul: İstanbul Üniverisitesi.İstanbul Üniversitesi Sosyal Bilimler Enstitüsü: Yayınlanmamış Yüksek Lisans Tezi.

Atasoy, Emin (2011), Bizden Olan Ötekiler, Asimilasyon Klskacında Bulgaristan Türkleri. Bursa: MKM Yayınc1lık.

Aziz (2004). Epoppeyata Yablanovo Kniga Vtora. Sofya: Sopot-Anevo.

Dayığlu, Ali (2005). Toplama Kampından Meclis'e Bulgaristan'da Türk ve Müslüman Azınlığı. İstanbul: İletişim Yayınları.

Demirhan, Hasan (2017). Canlı Tanıklarıyla Belene Toplama Kampından Anavatan Türkiye’ye Zorunlu Göç. Ed. Osman Köse, Geçmişten Günümüze Göç (Cilt 2, s. 361-377). Samsun: Canik Belediyesi Kültür Yayınları.

Dimitrov, Vesselin (2000). In Search of a Homogeneous Nation: The Assimilation of Bulgaria's Turkish Minority, 1984-1985. Journal of Ethnopolitics and Minority Issues in Europe, 2-20.

Eminov, Ali (1997). Turkish and Other Muslim Minorities in Bulgaria. London: Hurst\&Company.

Lutem, Ömer Engin (2012). 1984-1989 Dönemi Türkiye'nin Bulgaristan Politikas1 ve 89 Göçü. Ed.Neriman Ersoy-Hacısaliğoğlu-Mehmet Hacısalioğlu, 89 Göçü Bulgaristan'da 1984-1989 Azınlık Politikalarl ve Türkiye'ye Zorunlu Göç (s. 137-169). İstanbul: Yıldız Teknik Üniversitesi Balkan ve Karadeniz Araştırmaları Merkezi.

Memişoğlu, Hüseyin (2002). Bulgaristan Türkleri’nin Sosyo-Ekonomik ve Kültürel Yap1s1. Türkler Ansiklopedisi C.20. Ankara: Yeni Türkiye Yayınları., s.615-631

Memişoğlu, Hüseyin (1992). Bulgaristan ve Bulgaristan'da Türk Azınlık Sorunu. (Ayrl Basım) Ankara: T.T.K., s.115-125.

Memişoğlu, Hüseyin (1995). Bulgaristan'da Türk Kültürü. Ankara: Türk Kültürünü Araştırma Enstitüsü.

Mutlu, Nasıf (2014). Doğancı Çobanın İzinde Umuda Yolculuk. Bursa.

Öztürk, Said (2012). Devlet Hikayeleri: Kimliğin Kaybı ve Yeniden/Yenisinin Kaza- 
nılması. Ed.Neriman Ersoy-Hacısalihoğlu-Mehmet Hacısalihoğlu， Bulgaristan'da 1984-89 Azınlık Politikaları ve Türkiye'ye Zorunlu Göç. İstanbul: Yıldız Teknik Üniversitesi Balkan ve Karadeniz Araştırmaları Merkezi.

Şimşir, Bilal N. (2012). Bulgaristan Türkleri. Ankara: Bilgi Yayınevi.

Şimşir, Bilal N. (1985). Türk Basınında Bulgaristan Türkleri. Ankara: Başbakanlık Basın-Yayın ve Enformasyon Genel Müdürlüğü.

Y1ldırım, Bülent (2018). Bulgaristan'da Türk Varlı̆ğ ve Nüfusu. İstanbul: İlgi Kültür Sanat Yayıncilik.

Yücetürk, Ahmet ( 2015). Kızll Cehennem, Türk Doktorunun Bulgaristan Belene Kampı Hatıraları. İstanbul: Yakın Plan. 